ISSN 1392-3196

Zemdirbyste-Agriculture, vol. 100, No. 1 (2013), p. 9-18

UDK 579.22:631.872:631.51 / DOI 10.13080/z-a.2013.100.002

\title{
Soil mineral nitrogen and microbial parameters as influenced by catch crops and straw management
}

\author{
Dalia JANUŠAUSKAITÉ ${ }^{1}$, Aušra ARLAUSKIENE² ${ }^{2}$, Stanislava MAIKŠTĖNIENE ${ }^{2}$ \\ ${ }^{1}$ Institute of Agriculture, Lithuanian Research Centre for Agriculture and Forestry \\ Instituto 1, Akademija, Kèdainiai distr., Lithuania \\ E-mail: daliaj@lzi.lt \\ ${ }^{2}$ Joniškèlis Experimental Station, Lithuanian Research Centre for Agriculture and Forestry \\ Joniškèlis, Pasvalys distr., Lithuania
}

\begin{abstract}
Agricultural management can affect soil chemistry, nutrient cycling and microbial properties, but the relationship among them is not well explored. Catch crops play an important role in decreasing nitrogen (N) leaching in the autumn, and thereby reduce undesirable environmental effects, improve soil physical and microbiological properties. We investigated the effect of catch crops and straw management on soil mineral nitrogen $\left(\mathrm{N}_{\min }\right)$ and microbial activity on a clay loam Gleyic Cambisol $(C M g)$. A two-factor experiment was set up: 1) catch crops (narrow-leafed lupin, mixture of narrow-leafed lupin and oats, white mustard and without catch crops), and 2) straw management methods (with and without). The total amount of bacteria and fungi, dehydrogenase and urease activity, and potential nitrification rate were assayed during two successive spring barley growing seasons. Also we determined $\mathrm{N}$ in the soil and soil leachate. Our experimental findings indicated that the $\mathrm{N}_{\min }$ dynamics in the soil and nitrate nitrogen $\left(\mathrm{N}-\mathrm{NO}_{3}\right)$ leaching depended on the catch crops, the amount of decomposers and the weather conditions. Cultivation of post-harvest catch crops in a clay loam Cambisol reduced $\mathrm{N}_{\text {min }}$ content by $50-62 \%$ at the $0-40 \mathrm{~cm}$ soil layer, stubble breaking in the autumn by $23-41 \%$, compared with the soil where the stubble had not been broken and no catch crops had been grown. Also, cultivation of catch crops reduced nitrate $\left(\mathrm{N}-\mathrm{NO}_{3}\right)$ concentration in the soil leachate by $32-62 \%$. The biological variables differed among all treatments, especially among years. Higher counts of heterotrophic bacteria and fungi and greater enzymatic activity were recorded in the plots with catch crops. Higher nitrification activity was established in the plots without catch crops. The amount of cellulose degrading bacteria did not differ significantly between the treatments. Further research is needed to get a better insight into the processes of mineralization and immobilization of catch crops' residues and soil $\mathrm{N}_{\min }$ and $\mathrm{N}^{-\mathrm{NO}_{3}}$ leaching in agricultural ecosystems.
\end{abstract}

Key words: catch crops, clay loam, microorganisms, mineral nitrogen.

\section{Introduction}

In agricultural production, a special emphasis is put on the nitrogen $(\mathrm{N})$ cycling. Negative effects of excess $\mathrm{N}$ in the environment have resulted in an elevated interest in the use of green manure as fertilizer (Tripolskaya et al., 2004). To compensate for the negative $\mathrm{N}$ balance in the soil, new environment-friendly crop production methods should be introduced which would minimize N-leaching. Researchers have reported that incorporation of straw, together with nitrogen-rich above ground biomass of catch crops promoted immobilisation of soil mineral nitrogen $\left(\mathrm{N}_{\min }\right)$, restored soil humus and improved aeration (Nadezhkin et al., 2006; Arlauskienè et al., 2009). After cereal harvesting, white mustard, oilseed rapes are sown as catch crops as nitrogen collectors from the soil (Torstensson, Aronsson, 2000). Catch crops also play an important role in increasing productivity of subsequent crops by improving soil physical, chemical, and biological properties. Catch crops can be leguminous or non-leguminous. Leguminous catch crops provide a substantial amount of biologically fixed $\mathrm{N}$ to the primary crop, as well as ease decomposition of organic matter due to their low carbon to nitrogen (C:N) ratio (Fageria et al., 2005). Literature findings indicate that during the autumn period catch crops can reduce nitrate losses in the soil by $10-20 \mathrm{~kg} \mathrm{ha}^{-1}$ by accumulating nitrogen in the biomass (Baggs et al., 2000).

The amount of nutrients recycled in an agricultural system depends on the quality and quantity of the plant biomass (Trinsoutrot et al., 2000, Jin et al., 2008). Some authors noted that $\mathrm{N}$ mineralization can be predicted by the C:N of the crop residue (Rahn, Lillywhite, 2002). In some cases, the C:N might be too simplistic a measure of degradability because it does not always reflect the accessibility of the $\mathrm{C}$ and $\mathrm{N}$ to the 
microbial population. Depending upon the composition of the material, the changes in microbial growth and availability of $\mathrm{N}$ can fluctuate over very short periods of days which lead to inaccuracy of results interpretation (Bradbury et al., 1993). Fresh plant material represents a readily available substrate for soil microorganisms, and the specific quality of the organic residues controls the decomposition rate and the related release of nutrients by soil microbial communities. Inclusion of legume crops in the rotation often increases microbial populations, their diversity, biomass, respiration and activity (Kumar, Goh, 2003). Bacteria and fungi are the most active decomposers of organic materials in soil. The incorporation of green manure stimulated growth and activity of the microbial communities (Stark et al., 2007). Soil enzymes are known to be involved in nutrient cycling, and as such, their activities can be used as potential indicators of nutrient cycling processes. In contrast to these beneficial effects of legume-based cropping systems, a study in Texas reported no differences in several enzyme activities involved in $\mathrm{C}, \mathrm{N}, \mathrm{P}$, and $\mathrm{S}$ cycling in a sandy soil between a peanut and cotton rotation and continuous cotton monoculture (Acosta-Martínez et al., 2003).

Numerous studies have compared soil structure, microbial properties and chemistry in $\mathrm{N}$ leaching in light soils. However, very few studies have dealt with $\mathrm{N}$ mineralization, leaching and soil microbial dynamics in clay loam soils. The aim of the current study was to investigate how different catch crops affect soil microbial activity and $\mathrm{N}$ leaching into soil water and $\mathrm{N}$ availability to subsequent plants.

\section{Materials and methods}

Experimental site and soil. Field experiments were conducted at the Lithuanian Institute of Agriculture's (currently - Lithuanian Research Centre for Agriculture and Forestry) Joniškèlis Experimental Station situated in the northern part of Central Lithuania's plain $\left(56^{\circ} 01^{\prime} 50^{\prime \prime} \mathrm{N}\right.$ and $24^{\circ} 10^{\prime} 10^{\prime \prime} \mathrm{E}$ ) in 2007-2008. The soil of the experimental site is Endocalcari-Endohypogleyic Cambisol (CMg-n-w-can), whose texture is clay loam on silty clay with deeper lying sandy loam. Parent rock of this soil is glacial lacustrine clay which at the depth of 70 $80 \mathrm{~cm}$ transits into morenic loam. Clay particles $<0.002$ $\mathrm{mm}$ in the Ap horizon $(0-30 \mathrm{~cm})$ account for $27.0 \%$, in $\mathrm{B}_{\mathrm{w}}$ horizon $(31-51 \mathrm{~cm})$ for $59.6 \%$, in $\mathrm{B}_{\mathrm{k}}$ horizon $(52-76 \mathrm{~cm})$ for $51.6 \%$, in $\mathrm{C}_{1}$ horizon $(77-105 \mathrm{~cm})$ for $10.7 \%$, in $\mathrm{C}_{2}$ horizon $(106-135 \mathrm{~cm})$ for $11.0 \%$. The tests were done in the soil with the following agrochemical characteristics of the ploughlayer $(0-25 \mathrm{~cm}): \mathrm{pH}_{\mathrm{KCl}}-6.4$, available $\mathrm{P}_{2} \mathrm{O}_{5}-$ $0.118-0.120$ and available $\mathrm{K}_{2} \mathrm{O}-0.240-0.265 \mathrm{~g} \mathrm{~kg}^{-1}, \mathrm{~N}_{\text {total }}$ $-0.017 \mathrm{~g} \mathrm{~kg}^{-1}$, humus $-0.221 \mathrm{~g} \mathrm{~kg}^{-1}$ soil. Soil bulk density in the ploughlayer is $1.3-1.4 \mathrm{Mg} \mathrm{m}^{-3}$, total porosity -40 $45 \%$, air-filled porosity $-8-10 \%$.

Field experiments. Seeking to ascertain the effects of various post-crops used as catch crops and straw on mineral nitrogen $\left(\mathrm{N}_{\text {min }}\right)$ dynamics and on microbial parameters in the soil research was done in a two-factor experiment set up in 2006, and the effects of measures used was monitored for two successive years in 2007 and 2008. Experimental design: factor A - winter wheat straw management: 1) removed from the field (NS), 2) chopped and spread (S); factor B catch crops: 1) without catch crops, stubble not broken (NCNB), 2) without catch crops, stubble broken (NCB), 3) narrow-leafed lupin (Lupinus angustifolius L.), stubble broken (NL), 4) mixture of narrow-leafed lupin and oats (Avena sativa L.), stubble broken (NL $+\mathrm{O})$, 5) white mustard (Sinapis alba L.), stubble broken (WM). Control treatment - straw removed from the field, without catch crops, stubble not broken.

Research was done in the conventional cropping system's rotation where after vetch and oats mixture winter wheat (Triticum aestivum L. var. lutescens) variety 'Ada' and catch crops were grown. The following crops were grown as catch crops: narrow-leafed lupin 'Boruta', mixture of narrow-leafed lupin and oats 'Migla' and white mustard variety 'Braco'. After cereal harvesting, straw was removed or chopped and spread (factor A), the stubble was broken (except treatment 1 , factor B) by a combined stubble breaker composed of arrow coulters arranged in two-rows, one row of disks and clod crushing rollers. Catch crops were sown on the day of wheat harvesting (10 08 2006). For optimal growth of white mustard (when straw was removed or chopped and spread) and for straw mineralization, ammonium nitrate $\left(45 \mathrm{~kg} \mathrm{ha}^{-1}\right.$ $\mathrm{N})$ was applied. In the middle of October, due to better incorporation of catch crops, their biomass was chopped by a disk breaker, at 10-12 cm depth, 10 days after ploughed at 24-25 cm depth. $\mathrm{N}_{\min }$ in the soil was investigated in the autumn before catch crops biomass incorporation and in the spring of the following year prior to barley (Hordeum vulgare L.) variety 'Aura' cultivation. With cereal straw used as fertilizer the soil received $4883 \mathrm{~kg} \mathrm{ha}^{-1}$ DM (dry matter) and $33.4 \mathrm{~kg} \mathrm{ha}^{-1} \mathrm{~N}$.

Microbial analyses were conducted in the laboratory of Department of Plant Pathology and Protection, Lithuanian Institute of Agriculture. Soil samples for microbial analyses were collected from the 0 to $20 \mathrm{~cm}$ depth using a $2.5 \mathrm{~cm}$ diameter soil core in June (vegetation period of barley), in 2007 and 2008. Each composite soil sample was homogenized after sieving, and used for the microbiological assays. Conventional dilution spreadplating was performed to assess the culturable bacterial and fungal colony forming units (cfu). For heterothrophic bacteria enumeration "Soy Tryptic" agar (TSA/10 agar, "Biochemika", Switzerland), and malt extract agar ("Liofilchem Diagnostici", Italy) for total fungal counts were used. The counts of cfu were corrected for moisture content of soil before the final counts were expressed as the number of cultivable bacterial and fungal cells per $1 \mathrm{~g}$ of dry soil. Fresh soil samples were used for all enzyme assays. Dehydrogenase activity was determined using the reduction of 2,3,5-triphenyltetrazolium chloride (TTC) method as described (Methods..., 1995) and results were expressed $\mu \mathrm{g} \mathrm{g}^{-1}$ TPF (triphenylformazan) dw (dry weight of soil) $24 \mathrm{~h}^{-1}$. The activity of urease (EC 3.5.1.5) was measured as described by Kandeler (Methods..., 1995). The urease activity estimation was based on the colorimetric determination of ammonium formation after enzymatic urea 
hydrolysis by buffered method. The released ammonium was determined spectrophotometrically at $630 \mathrm{~nm}$. Results were expressed as $\mu \mathrm{g} \mathrm{g}^{-1}$ ammonia nitrate $\left(\mathrm{N}^{-\mathrm{NH}_{4}}\right) \mathrm{h}^{-1}$ dry soil. The potential ammonium oxidation (potential nitrification) rate in soil was assayed as accumulated nitrite according to the rapid test by ammonium oxidation technique described in the draft standard ISO/DIS 15685:1999 for testing of the potential nitrification in soil. Results are expressed as $\mu \mathrm{g}$ $\mathrm{g}^{-1}$ of $\mathrm{NO}_{2}$ dry weight. Standard curves were obtained for each analytical run using serially diluted nitrite $\left(\mathrm{NaNO}_{2}\right)$ standards.

Soil and plant analyses. Before incorporating into the soil, the amount of catch crops' above ground biomass was weighed, and stubble of 5-7 cm height was left. Plant samples were taken from each plot, the plants were cut into pieces $2-5 \mathrm{~cm}$ in length and dried to an airdry weight in a well-aerated room. Samples were taken for the determination of dry matter (dried to a constant mass at $105^{\circ} \mathrm{C}$ ), nitrogen and organic carbon. The above ground biomass of all plants was recalculated into dry matter and nitrogen accumulation was calculated. Nitrogen and carbon in plant samples were determined by Dumas method and spectrophotometrically, crude fibre was measured after Henneberg and Stohmann method.

Soil samples for the determination of variation of $\mathrm{N}_{\text {min }}\left(\mathrm{N}-\mathrm{NO}_{3}+\mathrm{N}-\mathrm{NH}_{4}\right)$ were taken from the $0-40$ and $40-80$ $\mathrm{cm}$ depths in the autumn before incorporating catch crops biomass and early in spring before spring cereal sowing from the $0-40 \mathrm{~cm}$ depth. To measure $\mathrm{N}-\mathrm{NO}_{3}$ leaching, in each straw management treatment in the plots of the main catch crops' species (Fabaceae and Brassicaceae plants) and without catch crops $(10 \times 20 \mathrm{~m})$ in two replications polyethylene pipes (piezometres) were placed at the $0-80$ $\mathrm{cm}$ depth to collect leachate. The samples for analyses were taken in winter (08 12 2006) and in summer (14 07 2007). $\mathrm{N}-\mathrm{NO}_{3}$ in the soil and leachate was determined by ionometric method, $\mathrm{N}-\mathrm{NH}_{4}$ in the soil was measured by spectrophotometrical method.
Weather conditions. The growing season of catch crops (August-October 2006) was favourable, warm and wet. During the growing season of catch cops the amount of precipitation exceeded the long-term mean by $85.5 \mathrm{~mm}$. The period from November 2006 to April 2007 was warmer than usual, except for February. Early in spring, in March and April there was little precipitation. In 2007, May-July period was relatively warm and wet. As a result, conditions were especially favourable for cereal growing. In August, September, October the mean daily temperature was higher than the long-term mean. The period from November 2007 to April 2008 was one of the warmest and wettest. In 2008, March and April were distinguished by higher precipitation rate (when the amount of precipitation exceeded the long-term mean by 16.8 and $17.2 \mathrm{~mm}$ ). In 2008, the mean daily air temperature during the main crops' growing season differed little from the long-term mean; however, this period was one of the driest ones. This impeded plant nutrient uptake from the soil. However, June and July were very wet.

Statistical analysis. The data were reported as mean from three replicates and were processed using a two-way analysis of variance (ANOVA) procedures. Significant differences among treatment means were assessed by Fisher's least significant difference test (LSD, $P<0.05$ and $P<0.01$ ). Statistical computations were performed using the statistical software package Statgraphics Plus 6.0.

\section{Results}

Catch crops. The yield of above ground mass of catch crops significantly $(P<0.01)$ depended on the plant species. The highest above ground mass was observed in white mustard 3620-3863 $\mathrm{kg} \mathrm{ha}^{-1}$ DM (Table 1). Application of straw tended to increase the above ground mass of narrow-leafed lupin and mixture of narrowleafed lupin and oats.

Table 1. Yield and characteristics of the above ground mass of catch crops

\begin{tabular}{|c|c|c|c|c|c|c|c|c|}
\hline \multirow{3}{*}{ Catch crops (B) } & \multicolumn{2}{|c|}{$\begin{array}{c}\text { mass } \\
\mathrm{kg} \mathrm{ha}^{-1} \mathrm{DM}\end{array}$} & \multicolumn{2}{|c|}{$\begin{array}{c}\mathrm{N} \\
\mathrm{kg} \mathrm{ha}^{-1}\end{array}$} & \multicolumn{2}{|c|}{$\mathrm{C}: \mathrm{N}$} & \multicolumn{2}{|c|}{$\begin{array}{l}\text { crude fibre } \\
\mathrm{mg} \mathrm{kg}^{-1}\end{array}$} \\
\hline & \multicolumn{8}{|c|}{ Straw management methods (A) } \\
\hline & NS & $\mathrm{S}$ & NS & $\mathrm{S}$ & NS & $\mathrm{S}$ & NS & $\mathrm{S}$ \\
\hline NL & $\begin{array}{l}1993 \\
(290) \\
\end{array}$ & $\begin{array}{l}2270 \\
(220) \\
\end{array}$ & $\begin{array}{l}58.4 \\
(8.5) \\
\end{array}$ & $\begin{array}{l}66.7 \\
(6.3) \\
\end{array}$ & $\begin{array}{c}15 \\
(0.3) \\
\end{array}$ & $\begin{array}{c}15 \\
(0.3) \\
\end{array}$ & $\begin{array}{r}293 \\
(5) \\
\end{array}$ & $\begin{array}{r}287 \\
(3) \\
\end{array}$ \\
\hline $\mathrm{NL}+\mathrm{O}$ & $\begin{array}{l}1467 \\
(80) \\
\end{array}$ & $\begin{array}{l}2117 \\
(180) \\
\end{array}$ & $\begin{array}{l}44.1 \\
(2.5)\end{array}$ & $\begin{array}{l}63.1 \\
(5.4) \\
\end{array}$ & $\begin{array}{c}14^{*} \\
(0.0)\end{array}$ & $\begin{array}{l}14^{*} \\
(0.3)\end{array}$ & $\begin{array}{l}322 \\
(4)\end{array}$ & $\begin{array}{l}285 \\
(4) \\
\end{array}$ \\
\hline WM & $\begin{array}{c}3863 * * \\
(60)\end{array}$ & $\begin{array}{c}3620^{* * *} \\
(530)\end{array}$ & $\begin{array}{c}113.6^{* *} \\
(1.7)\end{array}$ & $\begin{array}{c}140.8^{* *} \\
(20.6)\end{array}$ & $\begin{array}{l}13 * \\
(0.3)\end{array}$ & $\begin{array}{l}11^{* *} \\
(0.0)\end{array}$ & $\begin{array}{c}387^{* *} \\
(6)\end{array}$ & $\begin{array}{l}341^{*} \\
(25)\end{array}$ \\
\hline Means for factor A & 2441 & 2669 & 72.0 & $90.2 *$ & 14 & $13 * *$ & 334 & $304 * *$ \\
\hline Straw (A) & & ns & & 9.4 & & 242.0 & & 11,2 \\
\hline Catch crops (B) & & 32.3 & & 36.9 & & 122.1 & & 26.4 \\
\hline Straw $\times$ catch crops $(A \times B)$ & & n.s. & & n.s. & & 88.4 & & n.s. \\
\hline
\end{tabular}

Notes. NL - narrow-leafed lupin, NL + O - mixture of narrow-leafed lupin and oats, WM - white mustard, NS - straw removed from the field, $\mathrm{S}$ - spreading of chopped straw. DM - dry matter. Each value represents mean $(\mathrm{n}=3)$; standard deviation is included in parenthesis; n.s. - not significant at $P>0.05 .{ }^{*}$ - differences are statistically significant as compared to the control at $p<0.05$, $* *$ at $p<0.01$. 
Nitrogen content in the above ground mass of catch crops significantly depended on straw management as well as species of catch crops $(P<0.01)$. Nitrogen content was significantly higher by $55.2 \mathrm{~kg} \mathrm{ha}^{-1}$ in white mustard mass than of narrow-leafed lupin when straw was removed from the field and by $74.1 \mathrm{~kg} \mathrm{ha}^{-1}$ when straw was spread, respectively. The lowest nitrogen content was identified in the mixture of narrow-leafed lupin and oats, the $\mathrm{C}: \mathrm{N}$ of the above ground mass of catch crops was 11-15, the content of the crude fibre varied from 285 to $387 \mathrm{mg} \mathrm{kg}^{-1}$. Above ground mass of white mustard was described by the narrower $\mathrm{C}: \mathrm{N}$ and the highest content of crude fibre.

Soil mineral nitrogen $\left(N_{\text {min }}\right)$. Cultivation of catch crops had a significant $(P<0.01)$ effect on the change of $\mathrm{N}_{\min }$ in the $0-40 \mathrm{~cm}$ soil layer in the autumn
(Table 2). Irrespective of whether straw was removed from field or spread, all catch crops significantly reduced $\mathrm{N}_{\min }$ concentration in the soil by $50.1-61.5 \%$ and $23.3-$ $40.6 \%$, compared to the control treatment.

In general, significantly lower $\mathrm{N}_{\text {min }}$ content was observed with cultivation of $\mathrm{NL}+\mathrm{O}$ as well as WM, compared to the soil without catch crops.

$\mathrm{N}_{\text {min }}$ in the $0-40 \mathrm{~cm}$ soil layer was from 12.79 to $18.55 \mathrm{mg} \mathrm{kg}^{-1}$ and significantly depended on the catch crops and their interaction with straw $(P<0.01)$ in the first year of effect (in 2007) (Table 2). WM biomass increased $\mathrm{N}_{\min }$ significantly. The lowest $\mathrm{N}_{\min }$ was observed in the treatment with removed straw from field and with stubble broking or with incorporation of biomass of $\mathrm{NL}+\mathrm{O}$ mixture, 12.80 and $12.79 \mathrm{mg} \mathrm{kg}^{-1}$, respectively.

Table 2. The effect of catch crops and straw on the soil mineral nitrogen $\left(\mathrm{N}_{\text {min }}\right)$ and nitrate nitrogen $\left.(\mathrm{N}-\mathrm{NO})_{3}\right)$ concentrations in soil leachate

\begin{tabular}{|c|c|c|c|c|c|c|c|c|c|c|}
\hline \multirow{6}{*}{ Catch crops (B) } & \multicolumn{2}{|c|}{$\begin{array}{c}\text { Before } \\
\text { incorporation } \\
\text { of catch crop } \\
\text { biomass, } \\
2006\end{array}$} & \multirow{2}{*}{\multicolumn{4}{|c|}{$\begin{array}{cc}\begin{array}{c}\text { In spring } \\
\text { of the first year } \\
\text { of effect, } \\
2007\end{array} & \begin{array}{c}\text { In spring } \\
\text { of the second year } \\
\text { of effect, } \\
2008\end{array} \\
\begin{array}{l}\text { soil } \mathrm{N}_{\min } \text { concentration } \\
\mathrm{mg} \mathrm{kg}^{-1} \text { soil }\end{array}\end{array}$}} & \multirow{2}{*}{\multicolumn{4}{|c|}{$\begin{array}{cc}\begin{array}{c}\text { Late autumn, } \\
\text { after catch } \\
\text { crops and straw } \\
\text { ploughing-in, } \\
2006\end{array} & \begin{array}{c}\text { Summer, } \\
\text { spring barley } \\
\text { milky stage, }\end{array} \\
\mathrm{N}^{-\mathrm{NO}_{3} \text { concentration }} \\
\mathrm{mg} \mathrm{L}^{-1} \text { in soil leachate }\end{array}$}} \\
\hline & & & & & & & & & & \\
\hline & \multicolumn{10}{|c|}{ soil layer, cm } \\
\hline & \multicolumn{2}{|c|}{$0-40$} & \multicolumn{2}{|c|}{$0-40$} & \multicolumn{2}{|c|}{$0-40$} & \multicolumn{4}{|c|}{$0-80$} \\
\hline & \multicolumn{10}{|c|}{ Straw management methods $(\mathrm{A})$} \\
\hline & NS & $\mathrm{S}$ & NS & $\mathrm{S}$ & NS & $\mathrm{S}$ & NS & S & NS & $\mathrm{S}$ \\
\hline NCNB & $\begin{array}{l}15.62 \\
(0.79)\end{array}$ & $\begin{array}{l}13.94 \\
(0.15)\end{array}$ & $\begin{array}{l}14.71 \\
(0.34)\end{array}$ & $\begin{array}{l}13.14 \\
(0.05)\end{array}$ & $\begin{array}{c}9.71 \\
(0.16)\end{array}$ & $\begin{array}{l}10.61 \\
(0.14)\end{array}$ & $\begin{array}{l}51.4 \\
(2.1)\end{array}$ & $\begin{array}{c}52.1 \\
(14.1)\end{array}$ & $\begin{array}{l}29.5 \\
(4.5)\end{array}$ & $\begin{array}{c}12.4 * * \\
(2.9)\end{array}$ \\
\hline NCB & $\begin{array}{l}9.28^{* *} \\
(1.39)\end{array}$ & $\begin{array}{c}11.98^{* *} \\
(1.65)\end{array}$ & $\begin{array}{l}12.80 \\
(0.75)\end{array}$ & $\begin{array}{l}16.85 \\
(0.58)\end{array}$ & $\begin{array}{c}11.44^{* *} \\
(0.05)\end{array}$ & $\begin{array}{c}9.43 \\
(0.17)\end{array}$ & - & - & - & - \\
\hline NL & $\begin{array}{l}6.54 * * \\
(0.61) \\
\end{array}$ & $\begin{array}{c}7.80 * * \\
(0.57)\end{array}$ & $\begin{array}{l}16.44 \\
(0.34) \\
\end{array}$ & $\begin{array}{l}14.98 \\
(0.54) \\
\end{array}$ & $\begin{array}{c}11.66^{* *} \\
(0.59) \\
\end{array}$ & $\begin{array}{c}9.67 \\
(0.55) \\
\end{array}$ & $\begin{array}{c}35.1^{*} \\
(3.8) \\
\end{array}$ & $\begin{array}{l}36.7 \\
(1.6) \\
\end{array}$ & $\begin{array}{l}40.7^{*} \\
(11.6) \\
\end{array}$ & $\begin{array}{c}13.7^{* *} \\
(8.2) \\
\end{array}$ \\
\hline $\mathrm{NL}+\mathrm{O}$ & $\begin{array}{l}6.48 * * \\
(0.72)\end{array}$ & $\begin{array}{l}7.40 * * \\
(0.79)\end{array}$ & $\begin{array}{l}12.79 \\
(0.23)\end{array}$ & $\begin{array}{l}16.14 \\
(1.93)\end{array}$ & $\begin{array}{c}11.42^{* *} \\
(0.33)\end{array}$ & $\begin{array}{c}9.43 \\
(0.55)\end{array}$ & $\begin{array}{l}21.9^{*} \\
(1.10)\end{array}$ & $\begin{array}{l}31.7 \\
(6.5)\end{array}$ & $\begin{array}{l}37.3 \\
(3.4)\end{array}$ & $\begin{array}{c}18.0^{* * *} \\
(2.9)\end{array}$ \\
\hline WM & $\begin{array}{l}6.02 * * \\
(0.22)\end{array}$ & $\begin{array}{l}6.15^{* *} \\
(0.23)\end{array}$ & $\begin{array}{l}16.84 \\
(0.73)\end{array}$ & $\begin{array}{c}18.55^{* *} \\
(1.78)\end{array}$ & $\begin{array}{l}10.56 \\
(0.62)\end{array}$ & $\begin{array}{c}9.80 \\
(0.16)\end{array}$ & $\begin{array}{c}19.5^{* *} \\
(1.0)\end{array}$ & $\begin{array}{c}29.3^{*} \\
(6.9)\end{array}$ & $\begin{array}{l}32.4 \\
(2.4)\end{array}$ & $\begin{array}{c}18.1^{* * *} \\
(6.6)\end{array}$ \\
\hline Means for factor A & 8.79 & 9.45 & 14.72 & 15,93 & 10.96 & $9.79 * *$ & 32.0 & 37.5 & 35.0 & $15.5^{* *}$ \\
\hline Straw (A) & & n.s. & & n.s. & & 21.82 & & n.s. & & 103.63 \\
\hline Catch crops (B) & & 33.95 & & 5.16 & & n.s. & & 10.8 & & n.s. \\
\hline Straw $\times$ catch crops $(A \times B)$ & & n.s. & & 4.85 & & 5.19 & & n.s. & & n.s. \\
\hline
\end{tabular}

Notes. NCNB - without catch crop, stubble not broken, NCB - without catch crop, stubble broken, NL - narrow-leafed lupin, $\mathrm{NL}+\mathrm{O}-$ mixture of narrow-leafed lupin and oats, WM - white mustard, NS - straw removed from the field, $\mathrm{S}$ - spreading of chopped straw. Each value represents mean $(\mathrm{n}=3)$; standard deviation is included in parenthesis; ns - not significant at $P>0.05$. * - differences are statistically significant as compared to the control at $p<0.05, *^{*}$ - at $p<0.01$.

In the second year of effect (in 2008), $\mathrm{N}_{\text {min }}$ content in the soil was $9.43-11.66 \mathrm{mg} \mathrm{kg}^{-1}$ (Table 2). During this period, $\mathrm{N}_{\min }$ content changes were significantly affected by straw and its interaction with catch crops $(P<0.01)$. In the plots where straw had been applied, $\mathrm{N}_{\text {min }}$ content reduced from 0.76 to $1.99 \mathrm{mg} \mathrm{kg}^{-1}$ compared with the soil where straw had been removed. Incorporation of catch crops' biomass and stubble breaking had only a tendency to increase $\mathrm{N}_{\min }$ concentration in the soil.
Soil leachate. Late in the autumn (in 2006), in the plots without catch crops and without straw, the concentration of $\mathrm{N}-\mathrm{NO}_{3}$ in soil leachate exceeded the level of $50 \mathrm{mg} \mathrm{L}^{-1}$. However, the cultivation of catch crops and incorporation of their biomass significantly decreased $(P<0.01)$ the concentration of $\mathrm{N}-\mathrm{NO}_{3}$ in soil leachate (Table 3 ). According to mean data for factor $\mathrm{B}$, the lowest $\mathrm{N}-\mathrm{NO}_{3}$ concentration was identified for $\mathrm{NL}+\mathrm{O}$ and $\mathrm{WM}$ treatments. 
In the summer of 2007, during the milky stage of spring barley, the concentration of $\mathrm{N}-\mathrm{NO}_{3}$ in soil leachate was significantly lower in all plots where straw had been applied. Incorporated biomass of narrow-leafed lupin and its mixture with oats significantly increased $\mathrm{N}-\mathrm{NO}_{3}$ content (by 11.2 and $7.8 \mathrm{mg} \mathrm{L}^{-1}$, respectively).

Soil biology. Soil bacteria count at the $0-20 \mathrm{~cm}$ was significantly $(P<0.05)$ higher under all catch crops, especially under $\mathrm{WM}$ and $\mathrm{NL}+\mathrm{O}$ mixture sown after cereal harvesting in the first year and in plots with straw (average $13.7 \times 10^{6} \mathrm{cfu} \mathrm{g}^{-1} \mathrm{dw}$ ), and lower under without catch crop (average $11.510^{6} \mathrm{cfu} \mathrm{g}^{-1} \mathrm{dw}$ ) (Fig., Table 3). In the treatment with straw, the highest amount of bacteria was in the plots with WM, where $17.12 \times 10^{6} \mathrm{cfu} \mathrm{g}^{-1} \mathrm{dw}$ was detected. In the plots without straw a trend of bacteria increasing was recorded for the $\mathrm{NL}+\mathrm{O}$ treatment. The second impact year showed the opposite results - no significant influence of catch crop, bacteria counts even decreased in the plots with catch crop without straw. In the plots with straw, the impact of catch crops on bacteria amount was positive.
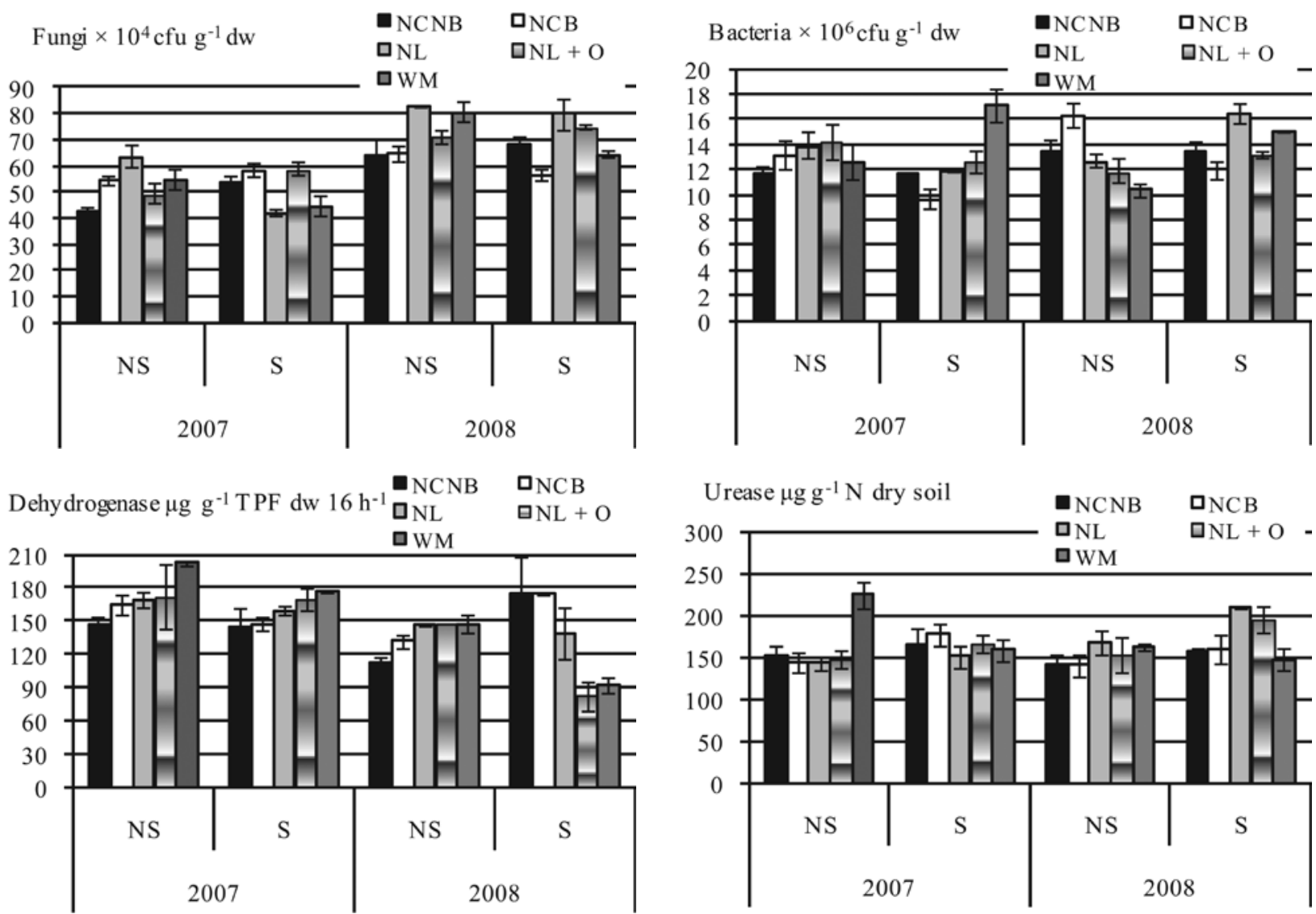

Nitrification $\mu \mathrm{g} \mathrm{g}{ }^{-1} \mathrm{NO}_{2} \mathrm{dw}$
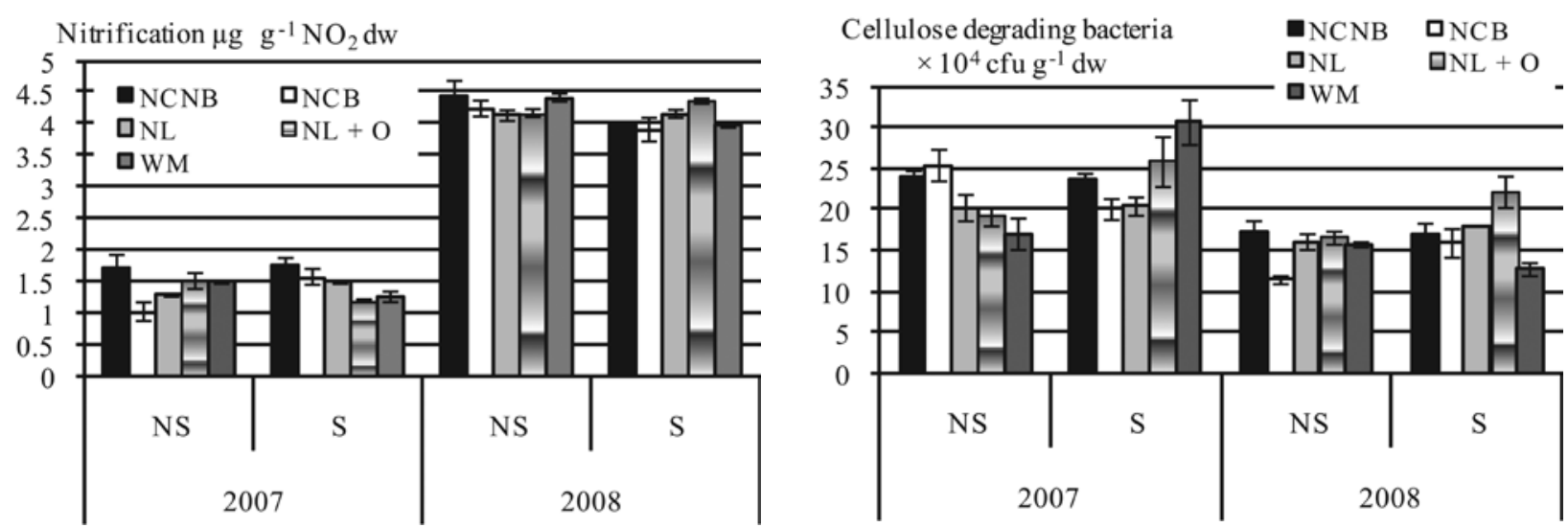

Notes. NCNB - without catch crop, stubble not broken, NCB - without catch crop, stubble broken, NL - narrow-leafed lupin, $\mathrm{NL}+\mathrm{O}$ - mixture of narrow-leafed lupin and oats, $\mathrm{WM}$ - white mustard; NS - straw removed from the field, $\mathrm{S}$ - spreading of chopped straw; TPF - triphenylformazan, dw - dry weight, cfu - colony forming units. Bars represent mean and standard error (SE).

Figure. Soil fungi and total bacteria, potential nitrification and dehydrogenase activity, cellulose degrading bacteria and urease activity in the arable layer under different cropping systems in a loamy soil after the first (2007) and the second (2008) sampling year 
Table 3. The influence of straw management and catch crop on soil microbial parameters

\begin{tabular}{ccccccc}
\hline Variables & Bacteria & Fungi & Dehydrogenase & Urease & Nitrification & $\begin{array}{c}\text { Cellulose } \\
\text { degrading } \\
\text { bacteria }\end{array}$ \\
\hline Catch crop & n.s. & 0.08 & n.s. & n.s. & 0.0759 & n.s. \\
Straw & n.s. & n.s. & n.s. & 0.041 & n.s. & 0.022 \\
Catch crop $\times$ straw & $<0.001$ & 0.001 & 0.061 & 0.004 & n.s. & 0.075 \\
Year & n.s. & $<0.001$ & 0.002 & n.s. & $<0.001$ & $<0.001$ \\
Catch crop $\times$ year & n.s. & 0.039 & 0.059 & 0.008 & n.s. & n.s. \\
\hline
\end{tabular}

Note. This table provides $\mathrm{P}$ values for main effects and interaction derived through analysis of variance (ANOVA).

Catch crops had significant impact on fungi amount, there was overall higher fungi amount in the next year. Especially in the second year - fungi count in the soil with catch crop was 75.36 , and without $-63.4 \times$ $10^{4} \mathrm{cfu} \mathrm{g}^{-1} \mathrm{dw}$. The straw management did not significantly affect the amount of fungi during both years. However, it was found that straw tended to slightly decrease the amount of fungi. Higher amount of fungi either without or with straw was in NL plots.

The effects of straw on nitrification rate in 2007 were not significant, but higher in NCNB plots than in the treatments with catch crop both in the plots with straw or without (Fig., Table 3). Nitrification activity in general was $191 \%$ higher in the next year. Potential nitrification rate was significantly higher in the plots without catch crop with stubble not broken either with or without straw in the first year. In the second year of impact, in the plots without straw there were slight differences in nitrification activity, but there were higher activities under NL and $\mathrm{NL}+\mathrm{O}$ plots with straw.

Straw management showed significant negative impact on dehydrogenase activity during experiment (Fig., Table 3). In general, the activity of dehydrogenase in the plots with straw significantly decreased from 170.59 to $159.55 \mu \mathrm{g} \mathrm{g}^{-1}$ TPF dw $24 \mathrm{~h}^{-1}$ in the first year. Dehydrogenase activity was higher in the first year after incorporation of catch crops and ranked as - NCNB < $\mathrm{NCB}<\mathrm{NL}<\mathrm{NL}+\mathrm{O}<\mathrm{WM}$ in the plots either with or without straw. The positive impact of catch crops on dehydrogenase activity persisted in the second year in the plots without straw. Conversely, in the second year dehydrogenase activity significantly decreased in the plots with $\mathrm{NL}+\mathrm{O}$ and WM with straw. Without straw, different catch crops showed very similar effect on dehydrogenase activity $-146.1-147.8 \mu \mathrm{g} \mathrm{g}^{-1} \mathrm{TPF} \mathrm{dw}$ $24 \mathrm{~h}^{-1}$.

The amount of cellulose degrading microorganisms varied inconsistently among the treatments (Fig., Table 3). In both years, higher amounts of cellulose degrading microorganisms were identified in the treatments with straw, especially in the plots with $\mathrm{NL}+\mathrm{O}$ and WM. However, catch crops had negative impact in the plots without straw. The total amount of cellulose degrading microorganisms in the second year was $42 \%$ lower in WM plots with straw compared with other plots.
Positive impact of straw on urease activity was noted in the next year (Fig., Table 3). In WM plots without straw the activity of urease showed significant activity and was higher by $54.6 \%$ than in the plots with NL or $\mathrm{NL}+\mathrm{O}$ in the first year. The effect of the catch crops on urease activity in the plots with straw was similar and lower than in the plots without catch crop. Higher urease activity was noted in the plots where stubble had been broken. In the second year of impact, we noted positive influence of catch crops, especially in NL and WM plots without straw. Also higher activity was detected in NL and $\mathrm{NL}+\mathrm{O}$ plots with straw. However, urease activity in WM plots decreased by $6.3 \%$, compared with the plots without catch crops.

\section{Discussion}

This study investigated how the biochemical quality and quantity of catch crop residues affect the subsequent mineralization of nitrogen and biota activity and the duration of this effect. An important stage from the environmental protection viewpoint is mineralization of incorporated crops biomass and straw as well as $\mathrm{N}$ release. Catch crops decreased mineral nitrogen $\left(\mathrm{N}_{\min }\right)$ content in both soil layers $(0-40 \mathrm{~cm}$ and $40-80 \mathrm{~cm})$ compared with the treatment without catch crops. Our research data agree with those of other researchers, who found less nitrogen (not exceeding European Union's allowable limits) in soil leachate after cultivation of catch crops in a crop rotation (Hooker et al., 2008). Legumes, as the postharvest catch crop, are not effective for nitrogen capture from the soil due to symbiotic nitrogen fixation. It was noted by other researchers (Tripolskaya et al., 2004), though, their cultivation in mixtures with Poaceae increased their efficiency as catch crops. With reduced $\mathrm{N}_{\min }$ content in the soil there was lower nitrate concentration in soil leachate $(r=0.62, P<0.05)$. The straw incorporation can also reduce the nitrogen leaching (Jin et al., 2008) due to high $\mathrm{N}$ immobilization (Vinten et al., 2002). When straw was incorporated into the upper soil layer by a stubble breaker, part of nitrogen presumably was included into the biomass of microorganisms or soil organic matter, therefore $\mathrm{N}_{\min }$ content in the $0-40 \mathrm{~cm}$ soil layer decreased. Literature data indicated that immobilized nitrogen content is dependent upon level of $\mathrm{N}_{\min }$ in soil as well as environmental conditions (soil temperature and moisture) (Giacomini et al., 2007). Vinten et al. 
(2002) indicated that poor soil aeration resulted in much lower $\mathrm{N}$ immobilisation and remineralisation, which is characteristic of heavy-textured soils.

Decomposition of catch crops' organic matter was rather intensive due to long warm autumn and mild winter, and in spring in the $0-40 \mathrm{~cm}$ soil layer large amount of $\mathrm{N}_{\text {min }}$ was found. Many autumn-incorporated organic materials are stimulated by microbiological processes and release more $\mathrm{N}$ than can be retained by soils and crops, leading to nitrate leaching (Vinten et al., 2002). According to the data of Lithuanian researchers, incorporation of the green manure in autumn into sandy loam Luvisol significantly increased nitrogen leaching not only in October-November (Tripolskaya et al., 2004), but in spring and summer (by 52\%) of the next year, compared to the plots where no organic manure had been applied (Tripolskaja, Šidlauskas, 2010).

According to many researchers, mineralization and immobilization of incorporated organic matter are influenced by its chemical composition, especially $\mathrm{C}: \mathrm{N}$ (Justes et al., 2009). In our study, the $\mathrm{C}: \mathrm{N}$ in the above ground mass of various catch crops was favourable for decomposition and varied little depending upon the type of crops. Soil $\mathrm{N}_{\min }$ content in spring depended on the nitrogen content incorporated with catch crops $(r=0.84$, $P<0.01)$, as well as crude fibre $(r=0.60, P<0.05)$. Much higher $\mathrm{N}_{\min }$ content was observed in the soil, where nitrogen-rich biomass of white mustard was incorporated in the autumn.

After incorporation of biomass of catch crops together with straw, which has low $\mathrm{N}$ content $(\mathrm{C}: \mathrm{N}=81)$, mineralization of $\mathrm{N}$ was weaker and immobilization was stronger. In spring, $\mathrm{N}_{\min }$ data showed that partial remineralization of immobilized $\mathrm{N}$ occurred. Incorporation of only catch crops' biomass led to $\mathrm{N}_{\text {min }}$ increase by $6.31-9.90 \mathrm{mg} \mathrm{kg}^{-1}$, meanwhile when straw had been spread - by $7.18-12.40 \mathrm{mg} \mathrm{kg}^{-1}$ of soil, compared to that in the autumn. $\mathrm{N}$ immobilization occurs only during a limited period of time, sufficient to prevent part of the mineral $\mathrm{N}$ pool from leaching, and net $\mathrm{N}$ mineralization can be expected during the subsequent cropping season, thus enhancing synchronization of $\mathrm{N}$ supply and demand (Trinsoutrot et al., 2000; Vinten at al., 2002; Justes et al., 2009). Another factor, which determines decomposition is soil properties, i.e. more nitrate is leached from sandy soil than from clay soil, it is likely that mineralization takes place; however, a large part of the nitrogen as the partial degradation products of microbial activity is permanently bound to clay particles (Sądej, Przekwas, 2008).

In the summer of 2007, nitrate concentration in soil leachate under the effect of straw was 2.2 times lower than under incorporated biomass of catch crops without straw. It indicates that mineralization of immobilized $N$ reduced. During the second year (2008) the straw impact on $\mathrm{N}_{\min }$ content in soil was significantly lower. Other researchers also indicate that during the second year, the content of remineralized nitrogen, used by plants, was significantly lower (Nadezhkin et al., 2006). This signals the start of the stabilization of soil organic matter, or immobilized N "aging", which may lead to lower nitrogen loss. According to the studies of other authors, incorporation of biomass of catch crops together with straw during the second year of effect, partially increase the content of stable humic acids (Arlauskienè et al., 2009).

The mineralization of $\mathrm{N}$ is driven by microorganisms and most of the identifiable organic $\mathrm{N}$ compounds in soil and leachate seem to be of microbial origin. Also the kinetics of organic $\mathrm{C}$ and $\mathrm{N}$ transfer through soil biomass pools (e.g., bacteria, fungi, enzyme) control $\mathrm{N}$ availability for winter leaching and for plant uptake the following spring (Vinten et al., 2002). The studied biological indicators were related to differences in catch crops properties and straw management. In general, the microbial activity differed between the treatments and was affected primarily by catch crop management and to a lesser degree by straw management. In many cases, the second year impact had weaker influence than the first year after the catch crop incorporation. Others studies suggested a large increase in soil microbial biomass, aerobic bacteria, and fungi after incorporation of organic substrates as wheat straw and green manure (Malik et al., 1998). Results showed that only potential nitrification rate and fungi amount were higher in the next year. Overall, the amount of fungi increased by $36 \%$ compared to the first year and it may be related to the fact that the fungi are more abundant during the final stages of decomposition when the organic material has been changed to a more digestible form. Plants can affect microbial activity and the decomposition rates of soil nutrient pools either through exudative growth induced changes in the soil, or via the composition of the incorporated plant residues (Rahn, Lillywhite, 2002). Plant type was reported to have a greater influence on the microbial biomass and enzyme activities (Stark et al., 2007). Campbell et al. (1991) observed increased fungal community after application of non-legume residues and increased bacterial populations after application of legume residues to the soil. A significant difference in catch crop effects between legumes and non-legumes was found in our study. In the presented field experiments lupine influenced fungi development more positively than mustard in the plots without straw. Because legumes have a narrow $\mathrm{C}: \mathrm{N}$ they favour bacterial activity (Wichern et al., 2004), but when catch crops grow for a short time they have the same C:N. Although $\mathrm{N}$ amount in lupine was twice as high as in mustard, due to a small difference in $\mathrm{C}: \mathrm{N}$ we did not find that $\mathrm{C}: \mathrm{N}$ of catch crops had strong impact on microbial population. According to other studies (Gilmour et al., 1998), the initial quality or C:N of the residues is not a reliable predictor of mineralization. As stated by Trinsoutrot et al. (2000), the $\mathrm{N}$ concentration of the residues is sufficient to predict the net effects of crop residues on soil mineral $\mathrm{N}$ dynamics. Crop residues with a wide $\mathrm{C}: \mathrm{N}$, such as straw, can temporarily immobilize soil $\mathrm{N}$ in the microbial biomass, resulting in less soil $\mathrm{N}_{\min }$ available for plant uptake and for microbial transformation (Pandey, 2006). 
Changes in soil microbial activity were largely controlled by the quantity of dry matter of catch crop and $\mathrm{N}$. But the biomass of plants has no positive effect on microbial activity, as might have been expected in the plot with mustard. Only the amount of bacteria in the first year in mustard plots with straw was higher and may be related to slower mineralization of mustard in autumn, compared with legume, partly due to the faster mineralization rate of lupin residue (Carranca et al., 2009). Positive mustard effect was also established on dehydrogenase and urease activities in the treatments without straw compared with lupine with straw Although soil $\mathrm{N}_{\text {min }}$ content was similar under $\mathrm{NL}$ and $\mathrm{NL}+\mathrm{O}$ in the second year, values for microbial amount and fungi were different, and those for bacteria were higher under mixture. It may be concluded that soil $\mathrm{N}$ content affects biota.

Wheat straw incorporation increased the urease and nitrification activity in the first year and bacteria amount in the second year. Similar results were observed by Malik et al. (1998). If straw incorporation showed the strong $\mathrm{N}$ immobilization, it may be sufficient to prevent part of the mineral $\mathrm{N}$ pool from leaching. Also net $\mathrm{N}$ mineralization can be expected during the subsequent cropping season together with enhancing synchronization of N supply and demand (Jin et al., 2008). Our investigation suggests that with decreasing $\mathrm{N}_{\text {min }}$ concentration in the soil in the second growing season of barley, the impact on microbes decreased.

The microbial analysis showed clear differences between the two methods of stubble management. With stubble breaking the amount of fungi, bacteria and dehydrogenase activity in the plots without straw increased, while urease activity increased in the plots with straw. This could be expected since soil microorganisms would be in direct contact with the fresh organic matter due to broken stubble (Carranca et al., 2009). Stubbleretained treatments also demonstrated significantly greater biomass and activity of microorganisms and in some cases N cycling (Hoyle, Murphy, 2006). However, in our study nitrification rate increased during the second year, when decomposition process of incorporated catch crops was approaching the end. Although it was noted that in the soils with high nitrification rates nitrate leaching was the highest (Mann, Tolbert, 2000), we did not find any tangible relationship in our study. We observed only a trend that nitrification rates may be related to $\mathrm{N}$ content in the leachate in the first year. Nitrification rate was higher in the soils without catch crops; it was also shown that straw strongly decreased the nitrification rate in $\mathrm{NL}+\mathrm{O}$ in the first year.

The effects of catch crops and straw on the activity of enzymes varied. The activity of urease, dehydrogenase significantly increased in the plots with mustard. Furthermore, urease activity was also higher (up to two-fold) under catch crops without straw. Similarly to urease, the highest levels of dehydrogenase activity were found in the soil under catch crops. Soil dehydrogenase activity generally increased in the studied treatments in the order: $\mathrm{MCNB}<\mathrm{NCB}<\mathrm{L}<\mathrm{LO}<\mathrm{M}$. The tendency of negative straw impact on enzyme activity persisted in the next year too. A similar result was found in other studies where after incorporation of catch crop the activity of urease increased by $100 \%$, compared with the treatment without catch crop (Marcinkevičienè, Pupalienè, 2009). This study found that several soil enzyme activities can be used as indicators of ecological changes caused by catch crop and straw management practices.

Mineralization of the incorporated catch crop biomass is a microbial driven process; however, sometimes the results indicate a lack of relationship between the biological indicators and soil $\mathrm{N}_{\min }$. Some studies have revealed seasonal differences of $\mathrm{N}$ use, with a wide microbial biomass fluctuation during the summer or with the variation in weather conditions during the experiments (Jensen et al., 2005). Bigger part of crop residues have a short turnover time in soil and some authors noted that decomposition continues after one year or more (Trinsoutrot et al., 2000). Microbial activity during the early stages of decomposition or in the first impact year may be correlated with net $\mathrm{N}$ mineralization measured in subsequent barley, at which time maximum net $\mathrm{N}$ mineralization was expected for most residues. Also the differences in microorganism counts among the treatments may result from incomplete decomposition of incorporated catch crops when we found higher values in the second year. Additionally, this also means that the effect of catch crop on soil biological activity is rather transient.

\section{Conclusions}

1. The catch crops and stubble breaking practise reduced the amount of mineral nitrogen $\left(\mathrm{N}_{\text {min }}\right)$ content in the soil in the autumn. The chemical composition of catch crops controlled net $\mathrm{N}$ mineralization.

2. The influence of straw in the treatment was ambiguous. Straw exerted the minimum negative environmental impact when applied with the biomass of white mustard or mixture of narrow-leafed lupine + oats.

3. Catch crop biomass incorporated with the straw had the highest positive impact on fungi, bacteria, dehydrogenase and urease activity. During the first year of impact, biological soil activity was more influenced by catch crops; while in the second year - by straw.

4. In many cases, the first year impact of catch crops was stronger than that of the second year.

\section{Acknowledgements}

The paper presents research findings, obtained through the long-term research programme "Harmful organisms in agro and forest ecosystems" implemented by Lithuanian Research Centre for Agriculture and Forestry.

Received 06062012

Accepted 25102012 


\section{References}

Acosta-Martínez V., Zobeck T. M., Gill T. E., Kennedy A. C. 2003. Enzyme activities and microbial community structure of agricultural semiarid soils. Biology and Fertility of Soils, 38: 216-227 http://dx.doi.org/10.1007/s00374-003-0626-1

Arlauskienė A., Maikštènienè S., Šlepetienė A. 2009. The effect of catch crops and straw on spring barley nitrogen nutrition and soil humus composition. Zemdirbyste-Agriculture, 96 (2): 53-70

Baggs E. M., Watson C. A., Rees R. M. 2000. The fate of nitrogen from incorporated cover crop and green manure residues. Nutrient Cycling in Agroecosystems, 56: 153-163 http://dx.doi.org/10.1023/A:1009825606341

Bradbury N. J., Whitmore A. P., Hart P. B., Jenkinson D. S. 1993. Modelling the fate of nitrogen in crop and soil in the years following application of $15 \mathrm{~N}$-labelled fertilizer to winter wheat. Journal of Agriculture Science, 121: 363-379 http://dx.doi.org/10.1017/S0021859600085567

Campbell C. A., Beiderbeck V. O., Zentner R. P., Lafond G. P. 1991. Effects of crop rotations and cultural practices on soil organic matters, microbial biomass and respiration on a thin Black Chernozem. Canadian Journal of Soil Science Society, 71: 363-376 http://dx.doi.org/10.4141/cjss91-035

Carranca C., Torres M. O., Baeta J. 2009. White lupine as a beneficial crop in Southern Europe. II. Nitrogen recovery in a legume-oat rotation and a continuous oat-oat. European Journal of Agronomy, 31 (4):190-194 http://dx.doi.org/10.1016/j.eja.2009.05.010

Fageria N. K., Baligar V. C., Bailey B. 2005. Role of cover crops in improving soil and row crop productivity. Communication in Soil Science and Plant Analysis, 36: 2733-2757 http://dx.doi.org/10.1080/00103620500303939

Giacomini S. J., Recous S., Aita C. 2007. Simulating the effects of $\mathrm{N}$ availability, straw particle size and location in soil on $\mathrm{C}$ and $\mathrm{N}$ mineralization. Plant and Soil, 301: 289-301 http://dx.doi.org/10.1007/s11104-007-9448-5

Gilmour J. T., Mauromoustakos A., Gale P. M., Norman R. J. 1998. Kinetics of crop residue decomposition: variability among or ratios between fractions have been used as predictors crops and years. Soil Science Society of America Journal, 62: 750-755 http://dx.doi.org/10.2136/ sssaj1998.03615995006200030030x

Hooker K. V., Coxon C. E., Hackett R., Kirwan L. E., O'Keeffe E., Richards K. G. 2008. Evaluation of cover crop and reduced cultivation for reducing nitrate leaching in Ireland. Journal of Environmentaly Quality, 37: 138-145 http://dx.doi.org/10.2134/jeq2006.0547

Hoyle F. C., Murphy D. V. 2006. Seasonal changes in microbial function and diversity associated with stubble retention versus burning. Australian Journal of Soil Research, 44 (4): 407-423 http://dx.doi.org/10.1071/SR05183

Jensen L., Salo T., Palmason F., Breland T., Henriksen T., Stenberg B., Pedersen A., Lundstrom Ch., Esala M. 2005. Influence of biochemical quality on $\mathrm{C}$ and $\mathrm{N}$ mineralisation from a broad variety of plant materials in soil. Plant and Soil, 273: 307-326 http://dx.doi.org/10.1007/s11104-004-8128-y

Jin K., Sleutel S., De Neve S., Gabriels D., Cai D., Jin J., Hofman G. 2008. Nitrogen and carbon mineralization of surface-applied and incorporated winter wheat and peanut residues. Biology and Fertility of Soils, 44: 661-665 http://dx.doi.org/10.1007/s00374-008-0267-5

Justes E., Mary B., Nicolardot B. 2009. Quantifying and modelling $\mathrm{C}$ and $\mathrm{N}$ mineralization kinetics of catch crop residues in soil: parameterization of the residue decomposition module of STICS model for manure and non-manure residue. Plant and Soil, 325: 171-185 http://dx.doi.org/10.1007/s11104-009-9966-4
Kumar K., Goh K. M. 2003. Nitrogen release from crop residues and organic amendments as affected by biochemical composition. Communication in Soil Science and Plant Analysis, 34: 2441-2460 http://dx.doi.org/10.1081/CSS-120024778

Malik V., Kaur B., Gupta S. R. 1998. Soil microbial biomass and nitrogen mineralization in straw incorporated soil. Ecological agriculture and sustainable development: proceedings of International Conference on Ecological Agriculture: Towards Sustainable Development, 1: 557-565

Mann L., Tolbert V. 2000. Soil sustainability in renewable biomass plantings. AMBIO: a Journal of the Human Environment, 29 (8): 492-498

Marcinkevičienė A., Pupalienė R. 2009. The enfluence of crop rotation, catch crop and manure on soil enzyme activities in organic farming. Zemdirbyste-Agriculture, 96 (1): 70-84

Methods in soil biology / Schinner F. et al. (eds). Berlin, Germany, 1995, $426 \mathrm{p}$.

Nadezhkin S. M, Lebedeva T. B., Aref'eva M. V. 2006. Effect of liming and fertilization on the fertility of leached chernozem and the productivity of grain-row crop rotation. Agrokhimiia, 10: 5-14

Pandey K. R. 2006. Soil management for better nutrition of lowland rice. Journal of the Institute of Agriculture and Animal Science, 27: 139-147

Rahn C. R., Lillywhite R. D. 2002. A study of the quality factors affecting the short-term decomposition of field vegetable residues. Journal of the Science of Food and Agriculture, 82 (1): 19-26 http://dx.doi.org/10.1002/jsfa.1003

Sądej W., Przekwas K. 2008. Fluctuations of nitrogen levels in soil profile under conditions of a long-term fertilization experiment. Plant, Soil and Environmental, 54 (5): 197-203

Stark Ch., Condron L. M., Stewart A., Di H. J., O'Callaghan M. 2007. Effects of past and current crop management on soil microbial biomass and activity. Biology and Fertility of Soils, 43 (5): 531-540 http://dx.doi.org/10.1007/s00374-006-0132-3

Torstensson G., Aronsson H. 2000. Nitrogen leaching and crop availability in manured catch crop systems in Sweden. Nutrient Cycling in Agroecosystems, 56: 139-152 http://dx.doi.org/10.1023/A:1009821519042

Trinsoutrot I., Nicolardot B., Justes E., Recous S. 2000. Decomposition in the field of residues of oilseed rape grown at two levels of nitrogen fertilisation. Effects on the dynamics of soil mineral nitrogen between successive crops. Nutrient Cycling in Agroecosystems, 56: 125-137 http://dx.doi.org/10.1023/A:1009838618133

Tripolskaja L., Šidlauskas G. 2010. The influence of catch crops for green manure and straw on the infiltration of atmospheric precipitation and nitrogen leaching. Zemdirbyste-Agriculture, 97 (1): 83-92 (in Lithuanian)

Tripolskaya L. N., Bagdanavichene Z. E., Romanovskaya D. K. 2004. Microbiological activity of soddy-podzolic soil and decomposition of organic fertilizers in the autumn-winter period. Eurasian Soil Science, 37 (9): 967-974

Vinten A. J. A., Whitmore A. P., Bloem J., Howard F., Wright F. 2002. Factors affecting $\mathrm{N}$ immobilisation/mineralisation kinetics for cellulose-, glucose- and straw-amended sandy soils. Biology and Fertility of Soils, 36: 190-199 http://dx.doi.org/10.1007/s00374-002-0524-y

Wichern F. T., Miiller R., Joergensen G., Buerkert A. 2004. Effect of manure quality and application forms on soil $\mathrm{C}$ and $\mathrm{N}$ turnover of a subtropical oasis soil under laboratory conditions. Biology and Fertility of Soils, 39: 165-171 http://dx.doi.org/10.1007/s00374-003-0689-z 
ISSN 1392-3196

Zemdirbyste-Agriculture, vol. 100, No. 1 (2013), p. 9-18

UDK 579.22:631.872:631.51 / DOI 10.13080/z-a.2013.100.002

\title{
Tarpinių pasėlių bei šiaudų įtaka dirvožemio mineralinio azoto kiekiui ir mikrobiologinėms savybėms
}

\author{
D. Janušauskaité ${ }^{1}$, A. Arlauskienè ${ }^{2}$, S. Maikštėniené2
}

${ }^{1}$ Lietuvos agrarinių ir miškų mokslų centro Žemdirbystès institutas

${ }^{2}$ Lietuvos agrarinių ir miškų mokslų centro Joniškèlio bandymų stotis

\section{Santrauka}

Žemès dirbimo sistemų ir įvairių technologijų taikymas turi įtakos dirvožemio cheminėms bei biologinėms savybėms, maisto medžiagų ciklo kitimui, tačiau ryšiai tarp jų ir sąveika nèra pakankamai gerai ištyrinėti. Tarpiniai pasėliai turi didelès reikšmės mažinant $\mathrm{N}$ išplovimą rudenį, nes mažina nepageidaujamą poveikį aplinkai, gerina dirvožemio fizikines ir mikrobiologines savybes. Tyrimų metu siekta nustatyti kaip tarpinių pasẻlių augintų skirtingų posėlinių augalų ir šiaudų naudojimo būdų įtaką mineralinio azoto ir mikroorganizmų veiklos intensyvumui giliau karbonatingame giliau glejjiškame rudžemyje (RDg4-k2). Buvo įrengtas dviejų veiksnių bandymas: 1) augalai (siauralapiai lubinai, siauralapių lubinų ir avižų mišinys, baltosios garstyčios) auginti kaip tarpiniai pasėliai ir be tarpinių augalų, 2) šiaudų naudojimo (su ir be) būdai. Bendras bakterijų bei mikromicetų kiekis ir dehidrogenazès, ureazès bei potencialios nitrifikacijos aktyvumas tirti kitus du vasarinių miežių auginimo sezonus. Taip pat nustatytas azoto kiekis dirvožemyje ir jo filtrate.

Tyrimų rezultatai parodè, kad dirvožemio mineralinio azoto $\left(\mathrm{N}_{\min }\right)$ dinamika ir nitratų $\left(\mathrm{N}-\mathrm{NO}_{3}\right)$ išplovimas priklausè nuo tarpinių augalų bei skaidytojų kiekio ir oro sąlygų. Tarpinių pasėlių auginimas po derliaus nuėmimo sunkaus priemolio rudžemio $0-40 \mathrm{~cm}$ sluoksnyje $\mathrm{N}_{\text {min }}$ kiekị sumažino $50-62 \%$, o ražienų skutimas rudenị 23-41\%, palyginti su dirvožemiu, kai ražienos nebuvo skustos ir jokie tarpiniai augalai nebuvo auginti. Be to, auginant tarpinius augalus, 32-62 \% sumažejo $\mathrm{N}_{-} \mathrm{NO}_{3}$ koncentracija dirvožemio filtrate. Biologiniai rodikliai skyrèsi tarp visų variantų, ypač tarp metų; didesnis bakterijų bei mikromicetų kiekis ir fermentinis aktyvumas nustatytas dirvožemyje, kuriame auginti tarpiniai augalai. Didesnis nitrifikacijos aktyvumas nustatytas plotuose be tarpinių pasėlių. Celiuliozę skaidančių bakterijų kiekis esmingai nesiskyrẻ tarp variantų. Siekiant geriau suprasti agroekosistemų augalų liekanų mineralizacijos bei imobilizacijos ir $\mathrm{N}_{\min }$ bei $\mathrm{N}-\mathrm{NO}_{3}$ išplovimo iš dirvožemio procesus, reikia tolesnių tyrimų.

Reikšminiai žodžiai: mikroorganizmai, mineralinis azotas, sunkus priemolis, tarpiniai pasėliai. 